\title{
Comparing Urban Citizenship, Sanctuary Cities, Local Bureaucratic Membership, and Regularizations
}

\author{
David Kaufmann \\ University of Bern, KPM Center for Public Management, Schanzeneckstrasse 1, 3001 \\ Bern, Switzerland, +41 (0)31 631 5996, david.kaufmann@kpm.unibe.ch
}

Published in Public Administration Review, https://doi.org/10.1111/puar.13029

\begin{abstract}
Irregular migrants tend to live in dense urban settings. Cities respond to this phenomenon with a variety of urban immigration and citizenship policies in support of irregular migrants. These urban policies produce a disparity between local inclusion and national exclusion. This article describes and compares such urban policies, namely urban citizenship, sanctuary cities, local bureaucratic membership, and regularizations. Urban citizenship serves as the normative foundation of these policies because it claims membership for all people that inhabit a city. Regularization programs confer a national residency status to irregular migrants. Pro-immigration actors favor this policy, however, when regularizations are not possible, cities can turn to sanctuary city and local bureaucratic membership policies. It is important for practitioners to comprehend and potentially engage with these various types of urban policies since they are likely to travel to cities worldwide.
\end{abstract}




\section{Cities as Alternative Sites of Membership}

The intertwined trends of globalization, migration, and urbanization establish cities as sites of migration. Cities worldwide are experiencing a growing population of irregular migrants who tend to live in dense urban areas due to a higher likelihood of finding jobs and suitable accommodations, better access to relational, ethnic, social or cultural networks, and greater anonymity (Lee 2017). City governments feel a certain immediacy to support, protect, and regularize irregular migrants because they "are de facto members of the community - they work in the city, pay local taxes, are homeowners, tenants, or landlords in the city, send their children to local schools, attend city churches, shop in the city, etc.” (de Graauw 2014, 312). Thus, cities perceive irregular migrants as regular participants in the everyday life of their communities and not as abstract illegal constructs (Varsanyi 2006, 240). Based on the concept of jus domicili (i.e., membership upon residence), certain cities perceive themselves as an alternative locus of economic, social, and political membership for all types of residents. Irregular migrants have become an urban policy target group. Cities engage in the formulation and implementation of a variety of migration and citizenship policies in support of irregular migrants, although they do not possess the legal power to expand these migrants' de jure rights. By formulating these policies, often in cooperation with local NGOs (Sidney 2014), cities can take a direct policy stance against national immigration and citizenship policies (Bauder 2017; de Graauw 2014). This is especially the case as national policies that target irregular migrants in the Global North have become stricter (de Haas et al. 2016). Conflicting urban and national policies towards irregular migrants produce a disparity between local inclusion and national exclusion (Bauder 2017; de Graauw 2014; Gebhardt 2016; Varsanyi 2006). 
Urban policies towards irregular migrants often confront or complement national policies, and they challenge national sovereignty over immigration and citizenship. It is, however, not a new phenomenon that cities are at the forefront of addressing societal problems. Cities are arenas where societal problems accentuate themselves and where socioeconomic transformations, developments, and problems first manifest themselves (Magnusson 2011). Thus, addressing societal problems is a constant urban policy task. Urban policy-making operates within the tension of complying with policies of higher-tier governments and formulating progressive and problem-oriented policies; a tension that is apparent in different urban policy fields, such as environmental (Sapotichne and Jones 2012; Hughes 2017) or drug policy (Kübler and Wälti 2001).

The goal of this article is to describe and compare the existing variety of urban immigration and citizenship policies towards irregular migrants. This article elaborates on the ambiguously used concepts, policies, and practices that exist on the ground and in the scholarly discourse. It begins by describing and comparing urban citizenship, sanctuary cities, local bureaucratic membership, and regularization programs, and it briefly introduces empirical examples from cities worldwide. The article ends by discussing the interdependencies between these policies and by highlighting the implications for practitioners.

\section{Urban Citizenship: The Normative Foundation}

Urban citizenship serves as the normative foundation of urban immigration and citizenship policies in support of irregular migrants as it argues for an alternative locus of membership (i.e., the city), regardless of residency status (de Graauw 2014; Varsanyi 2006). It proposes an ideal upon where citizenship is no longer bound to an a priori political community but is based upon the mere reality of presence and residence in a place (Varsanyi 2006). In this 
way, urban citizenship challenges the authority of the nation state over immigration and citizenship

Scholars and activists often discuss urban citizenship in association with the idea of the 'right to the city', which emphasizes the interests of all people who inhabit the city (Lefebvre 1968; Purcell 2003). This Lefebvrian ideal of inhabitance unhinges national citizenship as the primary political community, and instead, proposes that residence and lived presence in an urban space is the most central fact of membership (Purcell 2003; Varsanyi 2006). Urban citizenship contrasts the 'formal citizenship' of the nation state with the so-called 'substantive citizenship’ of the city (Holston and Appadurai 1999). In this perspective, the city is not mainly the lowest administrative level of a nation state but rather it is its own polity anchored in the everyday life of its residents (Magnusson 2011). Thus, urban citizenship empowers cities to formulate their own immigration and citizenship policies.

\section{Varieties of Urban Immigration and Citizenship Policies}

Nation states define irregular migrants as migrants who enter a country illegally, either by crossing a border undetected, using false documents or having entered a country legally and then having fallen out of that legal status or allowing their legal status to lapse — such as students, temporary workers, rejected asylum seekers, or tourists (Levinson 2005). It is estimated that nearly 12 million irregular migrants live in the US (Gonzalez et al 2019, 10) and about 7 to 30 million live in Europe (1 to 4 percent of the European population) (CLANDESTINO 2009). Table 1 compares three existing urban immigration and citizenship policies towards irregular migrants. The following sections discuss the individual policies and their interdependences. 
Table 1: Urban immigration and citizenship policies

\begin{tabular}{l|l|l|l} 
& Sanctuary Cities & $\begin{array}{l}\text { Local Bureaucratic } \\
\text { Membership }\end{array}$ & Regularizations \\
\hline Content & Not necessarily & No \\
\hline $\begin{array}{l}\text { Not controlling } \\
\text { residency status }\end{array}$ & Yes & Yes & Yes \\
\hline $\begin{array}{l}\text { Access to city } \\
\text { services }\end{array}$ & Not necessarily & Yes & $\begin{array}{l}\text { No, nation state mem- } \\
\text { bership }\end{array}$ \\
\hline $\begin{array}{l}\text { Urban member- } \\
\text { ship }\end{array}$ & Not necessarily & & \\
\hline
\end{tabular}

\begin{tabular}{l|l|l|l}
\hline Rationale & Policy and practice & Policy & Policy (programs) \\
\hline Type & $\begin{array}{l}\text { Logic of inter- } \\
\text { vention } \\
\text { national immigration } \\
\text { law and non-coopera- } \\
\text { tion with national im- } \\
\text { migration authorities }\end{array}$ & $\begin{array}{l}\text { Discretionary power in } \\
\text { policy-making }\end{array}$ & $\begin{array}{l}\text { Discretionary power in } \\
\text { implementation and } \\
\text { 'vertical venue-shop- } \\
\text { ping' }\end{array}$ \\
\hline $\begin{array}{l}\text { Understanding } \\
\text { of ‘the urban' }\end{array}$ & $\begin{array}{l}\text { The city as an alterna- } \\
\text { tive locus for citizen- } \\
\text { ship }\end{array}$ & $\begin{array}{l}\text { The city as the lowest } \\
\text { administrative level }\end{array}$ & $\begin{array}{l}\text { The city as the lowest } \\
\text { administrative level }\end{array}$ \\
\hline $\begin{array}{l}\text { Relation to na- } \\
\text { tional immigra- } \\
\text { tion framework }\end{array}$ & $\begin{array}{l}\text { Non-enforcement of } \\
\text { national immigration } \\
\text { laws }\end{array}$ & $\begin{array}{l}\text { Within national legal } \\
\text { framework }\end{array}$ & $\begin{array}{l}\text { Within national legal } \\
\text { framework }\end{array}$ \\
\hline \hline City examples & $\begin{array}{l}\text { Over 100 cities in the } \\
\text { United States, Amster- } \\
\text { dam }\end{array}$ & $\begin{array}{l}\text { New Haven, San Fran- } \\
\text { cisco, Los Angeles, } \\
\text { New York, Madrid }\end{array}$ & Barcelona, Geneva \\
\hline
\end{tabular}

\section{Sanctuary Cities}

In the US context, Gonzalez et al. $(2019,4)$ define a sanctuary city as "a city or police department that has passed a resolution or ordinance expressly forbidding city or law enforcement officials from inquiring into immigration status and/or cooperation with Immigration and Customs Enforcement”. Consequently, city governments protect their employees from the legal consequences of their actions. There are also so-called 'informal' sanctuary cities that have not formulated an official policy but that do not enforce national immigration policy (Gonzalez et al. 2019; Villazor 2008). Thus, a sanctuary city is one that ignores or does 
not enforce national immigration law and, as a consequence, does not cooperate with national immigration authorities. However, sanctuary cities are not able to guarantee the protection of irregular migrants from national immigration authorities in their territories. In its essence, a sanctuary city is a 'regime of practice' that deems residency status as irrelevant in the vast majority of interactions between residents and city employees (Mancina 2016).

San Francisco, largely symbolically, declared itself as a sanctuary city for immigrants in 1985 (Bauder 2017; Mancina 2016). In the following years, sanctuary cities became politicized in the US due to the claim that crime increased following sanctuary policies. Despite these political narratives, sanctuary policies have no effects on crime rates in US cities (Gonzalez et al. 2019). Sanctuary cities are a US-centered phenomenon that has emerged because US federal law does not oblige local governments to cooperate with federal immigration authorities. However, the idea that cities can provide a sanctuary for irregular migrants also resonates with Canadian and European cities, among others (Bauder 2017). For example, the Amsterdam city police refrain from checking the residency status of people that report a crime (Delvino 2017).

\section{Local Bureaucratic Membership}

Local bureaucratic membership aims to facilitate irregular migrants’ access to city services. A crucial feature of local bureaucratic membership is that local governments can issue urban or municipal ID cards that allow irregular migrants to identify themselves to relevant local actors, such as frontline city officials, the police, schools, hospitals, libraries, or local businesses. These urban ID cards are only valid in the city that issues them, and they do not confer a legal status to the holder, meaning that they cannot be used for permission to work, to drive, or to grant eligibility for any governmental benefits (De Graauw 2014). According to de Els de Graauw (2014), local bureaucratic membership is a pragmatic concept because 
it acknowledges national authority over immigration and citizenship. The city is understood to be the lowest administrative level, and local bureaucratic membership capitalizes on the discretionary administrative powers that cities have in dealing with irregular migrants.

The city of New Haven pioneered local bureaucratic membership policies in June 2007, followed by San Francisco in autumn 2007, Oakland in 2009, Richmond in 2011, Los Angeles in 2012, and New York in 2014 (de Graauw 2014). In Europe, Madrid created an urban ID card to ensure irregular migrants’ access to city services (Delvino 2017).

\section{Regularizations}

Regularization programs provide irregular migrants with a residency status within the legal immigration and citizenship framework of the nation state. There are various forms of regularization programs in practice: permanent or one-shot, individual or collective (see Apap et al. 2000). Most governments formulate certain criteria in order to limit who is eligible for these programs and, by doing so, they ultimately define who qualifies for regularization.

What makes these regularization programs specifically urban? On the one hand, cities can lobby relevant national governmental actors to establish regularization programs and, on the other hand, cities can take an active role in the implementation of such programs. In terms of lobbying, cities can make use of their political and economic leverage by engaging in ‘vertical venue-shopping’ (Sapotichne and Jones 2012), meaning that cities push for immigration and citizenship policy change at higher levels of government. As to the latter, cities can use their discretion in the implementation of regularization programs to the benefit of irregular migrants.

Geneva is a good example of how a city pushed for regularizations and made use of its discretionary power. Through its so-called 'Operation Papyrus' in 2017, Geneva was able to 
regularize around 1,100 out of its estimated 13,000 irregular migrants, including 412 children and 70 percent women. The Genevan authorities, together with local NGOs, formulated criteria, which define who are eligible for regularization under this program. The Federal government consented to 'Operation Papyrus', and it operates within the existing Swiss regularization frameworks. Similarly, Barcelona utilizes an opportunity in Spanish law to grant local status to irregular migrants. Spanish municipalities check the fulfillment of the criteria for obtaining such a local status, and Barcelona takes a benevolent implementation approach by favorably assessing integration requirements for irregular migrants (Gebhardt 2016).

\section{Interdependence of Urban Policies Towards Irregular Migrants}

The aforementioned urban immigration and citizenship policies are distinct, but interdependent. Urban citizenship considers the city as an alternative locus of membership. Thus, this concept underpins many urban immigration and citizenship policy discussions. Regularization programs operate within the legal framework of the nation state and these programs are therefore not as dependent on urban citizenship ideas. Immigrants and pro-immigration actors consider regularizations to be the desired policy solution because they offer the most rights and the highest certainty for irregular migrants. When regularizations are not legally possible or politically feasible, cities often turn to sanctuary city and local bureaucratic membership policies. In order for local bureaucratic membership policies to be credible, they must be accompanied by sanctuary city policies, meaning that being a sanctuary city is a necessary condition for local bureaucratic membership. This mutual dependence is visible in the thorny situations faced by Canadian cities: city governments facilitate access to services by refraining from checking residency statuses, but municipal police forces do not tend to adopt sanctuary practices (Bauder 2017). Although the combination of these two policies does not secure a regular status, they help irregular migrants to better cope with their precar- 
ious situation, and they constitute a viable policy alternative when regularization is not possible. Local bureaucratic membership policies are pragmatic urban policies (de Graauw 2014), however, the sanctuary city element adds a more controversial aspect to local bureaucratic membership.

\section{Conclusion and Implications for Practitioners}

This article describes and compares distinct but interdependent urban immigration and citizenship policies that support irregular migrants. The literature discussed is rather US-centric, however these ideas and policies are likely to travel to cities worldwide, as studies from Nairobi (Kassa 2019) or Buenos Aires (Bastia and Bressán 2018) reveal. The detailed content and configurations of these policies are context specific. This means that cities formulate these policies within their own urban contexts, in cooperation with local non-governmental actors and within the setting of national institutions and regulations. In general, cities have limited autonomy to formulate such policies, meaning that cities often settle for practical and informal practices.

This article raises four implications for practitioners. First, it is important for practitioners to be aware of the specificities of the full set of urban policies that support irregular migrants. Such urban policies have different goals, rest on different conceptualizations of 'the urban' and are often ambiguously labeled. Second, the ideas behind these policies are circulating globally. Mayors, as well as NGOs, are connected to and informed by each other. Local NGOs mainly discuss policies that support irregular migrants based on the normative ideas of 'urban citizenship' and 'the right to the city'. These claims are made locally but also in concert with social movements worldwide (Purcell 2014). Thus, it is likely that practitioners worldwide will be confronted with these ideas. Third, pro-immigration actors favor regularization programs because they offer the most certain status for irregular migrants. However, 
the design of such regularization programs requires existential decisions because the formulated criteria ultimately define who is worthy of a secure life (Ticktin 2011). Fourth, when regularization programs are not legally possible, or when higher-tier governments block them, cities have little choice but to turn to sanctuary city policies in combination with local bureaucratic membership. Cities that declare themselves as sanctuary cities are likely to provoke intergovernmental conflicts or situations of legal uncertainty. However, when cities are determined to advance solutions in favor of irregular migrants, sanctuary city policies in combination with local bureaucratic membership constitute a viable policy alternative. 


\section{References}

Apap, Joanna, Philippe de Bruycker, and Catherine Schmitter. 2000. Regularisations of Illegal Aliens in the European Union: Summary Report of a Comparative Study. Brussels: Bruylant Publishers.

Bastia, Tanja, and Jerónimo Montero Bressán. 2018. Between a guest and an okupa: Migration and the making of insurgent citizenship in Buenos Aires’ informal settlements. Environment and Planning A: Economy and Space 50(1): 31-50.

Bauder, Harald. 2017. Sanctuary cities: Policies and practices in international perspective. International Migration 55(2): 174-187.

CLANDESTINO. 2009. Undocumented Migration: Counting the Uncountable. Data and Trends Across Europe. https://emnbelgium.be/sites/default/files/publications/clandestino-final-report.pdf [accessed December 29, 2018].

De Graauw, Els. 2014. Municipal ID Cards for Undocumented Immigrants: Local Bureaucratic Membership in a Federal System. Politics \& Society, 42(3), 309-330.

De Haas, Hein, Katharina Natter, and Simona Vezzoli. 2016. Growing Restrictiveness or Changing Selection? The Nature and Evolution of Migration Policies. International Migration Review. Early Online.

Delvino, Nicola. 2017. European Cities and Migrants with Irregular Status: Municipal initiatives for the inclusion of irregular migrants in the provision of services. https://www.compas.ox.ac.uk/2017/european-cities-and-migrants-with-irregular-status/ [accessed December 29, 2018].

Gebhardt, Dirk. 2016. Re-thinking urban citizenship for immigrants from a policy perspective: the case of Barcelona. Citizenship Studies 20 (6-7): 846-866. 
Gonzalez, Benjamin, Loren Collingwood, and Stephen Omar El-Khatib. 2019. The Politics of Refuge: Sanctuary Cities, Crime, and Undocumented Immigration. Urban Affairs Review. 55(1): 3-40

Holston, James, and Arjun Appadurai. 1999. “Introduction: Cities and citizenship”. In Cities and citizenship, edited by J. Holston, 1-18. Durham: Duke University Press.

Hughes, Sara. 2017. The Politics of Urban Climate Change Policy: Toward a Research Agenda. Urban Affairs Review, 53(2), 362-380.

Kassa, Derese. 2019. Refugee Spaces and Urban Citizenship in Nairobi: Africa's Sanctuary City. Lanham: Lexington Books.

Kübler, Daniel, and Sonja Wälti. 2001. Drug Policy-Making in Metropolitan Areas: Urban Conflicts and Governance. International Journal of Urban and Regional Research, 25(1): 35-54.

Lee, June J.H., ed. 2017. World Migration Report 2015. Migrants and Cities: New Partnerships to Manage Mobility. Geneva: IOM.

Lefebvre, Henri. 1968. Le droit à la ville. Paris: Anthopos,.

Levinson, Amanda. 2005. The Regularisation of Unauthorized Migrants: Literature Survey and Country Case Studies. Oxford: University of Oxford, COMPAS. https://www.compas.ox.ac.uk/wp-content/uploads/ER-2005-Regularisation_Unauthorized_Literature.pdf [accessed December 29, 2018].

Magnusson, Waren. 2011. Politics of Urbanism: Seeing like a City. Abingdon: Routledge.

Mancina, Peter. 2016. "In the Spirit of Sanctuary: Sanctuary-City Policy Advocacy and the Production of Sanctuary-Power in San Francisco, California”. PhD. diss., Vanderbilt University. 
Purcell, Mark. 2003. Citizenship and the Right to the Global City: Reimagining the Capitalist World Order. International Journal of Urban and Regional Research 27(3): 564-590.

Purcell, Mark. 2014. Possible worlds: Henri Lefebvre and the right to the city. Journal of Urban Affairs 36(1): 141-154.

Sapotichne, Joshua, and Bryan D. Jones. 2012. Setting City Agendas: Power and Policy Change. In The Oxford Handbook of Urban Politics, edited by Karen Mossberger, Susan E Clarke, and Peter John, 442-467. New York: Oxford University Press.

Sidney, Mara. 2014. Outsiders/Insiders: How Local Immigrant Organisations Contest the Exclusion of Undocumented Immigrants in the US. In New Border and Citizenship Politics, edited by Helen Schwenken, and Sabine Russ-Sattar, 103-122. London: Palgrave Macmillan.

Ticktin, Miriam. 2011. Casualties of Care: Immigration and the Politics of Humanitarianism in France. Berkeley and Los Angeles: University of California Press.

Varsanyi, Monica W. 2006. Interrogating ‘Urban Citizenship’ vis-à-vis Undocumented Migration, Citizenship Studies, 10(2): 229-249.

Villazor, Rose Cuison. 2008. What is a Sanctuary?, Southern Methodist University Law Review, 61(1): 133-158. 